\title{
KEPUTUSAN PEMILIHAN FITUR EMISI SUKUK BANK UMUM SYARIAH
}

\author{
Taufik Awaludin \\ dosen01844@unpam.ac.id \\ Program Studi Manajemen, Universitas Pamulang
}

\begin{abstract}
This study aims to identify important elements and sub-elements in the aspect of features, which affect the Sharia Commercial Banks (BUS) in deciding sukuk issuance as well as providing relevant recommendations in issuing sukuk. The research method used are literature studies, in-depth interviews, and Analytical Network Process (ANP). The research results states that the dominant feature into consideration for Islamic Commercial Banks is the return feature followed by the emission value feature and the time period feature. The combination of dominant sub-elements for BUS in determining sequential features of sukuk issuance namely: the type of asset performance (return), the need for additional funds (emission value), the company's reputation (size), investor/market preferences (payment terms), and contracts and sukuk structures (guarantees). In deciding to issue sukuk, BUS should maintain the quality of assets or financing projects. Then BUS needs to have memorandum of understanding both with the BUMN business sector and other private sectors. Besides that BUS must also have good risk management.
\end{abstract}

Key Word: ANP, Features Aspect, Islamic Commercial Bank, Sukuk

\section{ABSTRAK}

Penelitian ini bertujuan mengidentifikasi sejumlah elemen dan sub-elemen penting dalam aspek fitur yang mempengaruhi Bank Umum Syariah (BUS) dalam memutuskan menerbitkan sukuk serta memberikan rekomendasi yang relevan dalam penerbitan sukuk. Metode penelitian yang digunakan adalah gabungan penelitian kualitatif antara studi literatur, wawancara mendalam dan Analytical Network Process. Hasil penelitian mendapatkan fitur yang dominan menjadi pertimbangan bagi Bank Umum Syariah adalah fitur return diikuti dengan fitur nilai emisi dan fitur jangka waktu. Adapun secara kombinasi sub-elemen dominan bagi BUS dalam menentukan fitur atas penerbitan sukuk secara berurutan: jenis kinerja aset (return), kebutuhan tambahan dana (nilai emisi), reputasi/size perusahaan ((jangka waktu), preferensi investor/market (term pembayaran), serta akad dan struktur sukuk (jaminan). Dalam memutuskan menerbitkan sukuk BUS terlebih dahulu perlu menjaga kualitas aset atau financing project yang dimilikinya. Kemudian BUS sedapat mungkin sudah mendapatkan MOU kerjasama proyek pembiayaan baik dengan sektor usaha BUMN maupun sektor swasta lainnya. Selain itu BUS juga harus memiliki manajemen pengelolaan risiko yang baik.

Kata Kunci: ANP, Aspek Fitur, Bank Umum Syariah, Sukuk

\section{PENDAHULUAN \\ Latar Belakang}

Pada sistem perbankan di Indonesia, telah menganut dual banking system dimana bank syariah beroperasi secara berdampingan dengan bank konvensional. Keberadaan bank syariah di Indonesia turut membantu pertumbuhan ekonomi pada sektor riil, karena bank syariah dapat berperan sebagai commercial banking sekaligus investment banking. Berdasarkan data dari Otoritas Jasa Keuangan (OJK) pada September 2018 terdapat 14 Bank Umum Syariah (BUS), 20 Unit Usaha Syariah dan 168 Bank Pembiayaan Rakyat Syariah (BPRS). Hingga akhir
September 2018, bank syariah mengalami keterbatasan modal. Dari 14 BUS, 13 BUS memiliki modal inti kurang dari Rp 5 Triliun dan hanya 1 BUS yang memiliki modal inti melebihi Rp 5 Triliun atau tergolong kategori BUKU 3. Kondisi permodalan yang terbatas merupakan faktor penting yang mempengaruhi rendahnya ekspansi aset perbankan syariah. Selain itu rasio kecukupan modal (CAR) BUS secara agregat hanya mencapai $21,25 \%$, lebih rendah dari CAR rata-rata bank umum secara nasional yang mencapai 22,91\%. Dengan demikian aset BUS dan UUS hingga September 2018 baru mencapai Rp 456,92 
Triliun atau hanya mencapai 5,93\% dari aset perbankan secara nasional.

Dengan kondisi demikian, bank-bank syariah menjadi kurang leluasa untuk membuka kantor cabang, mengembangkan infrastruktur, mengembangkan layanan perbankan yang bervariasi, termasuk layanan custodian, digital money dan trustee yang hanya dapat dilakukan oleh bank pada kategori BUKU 3 dan 4. Selain itu, bank syariah juga mengalami kendala dalam meningkatkan efisiensi dimana tingkat BOPO bank syariah mencapai $88,08 \%$ bila dibandingkan dengan perbankan secara nasional yang mencapai $79,13 \%$. Kemudian komposisi Dana Pihak Ketiga (DPK) bank syariah selama ini didominasi dari sumber dana jangka pendek, yaitu dalam bentuk deposito. Inefisiensi ini menyebabkan semakin tinggi biaya pembiayaan kepada nasabah, bank akan kesulitan menjaga likuiditas dan membiayai pembiayaan yang bersifat jangka panjang.

Salah satu alternatif untuk mengatasi masalah tersebut, bank syariah perlu mencari sumber pendanaan lain yang dapat berasal dari pihak eksternal. Sukuk merupakan salah satu cara bagi bank syariah untuk mendapatkan sumber pendanaan bagi perusahaan dari eksternal dalam meningkatkan pertumbuhan bisnisnya. Hingga September 2018, hanya terdapat 4 BUS yang telah menerbitkan sukuk, yaitu Bank Syariah Mandiri (BSM), Bank Muamalat Indonesia (BMI), Bank Negara Indonesia Syariah (BNIS) dan Bank Rakyat Indonesia Syariah (BRIS) sedangkan 10 BUS lain belum menerbitkan sukuk. Penerbitan obligasi atau sukuk akan memberikan dampak dan manfaat bagi bank. Prabowo (2003) dan Setiawan (2003), penerbitan obligasi dapat merubah dan meningkatkan struktur modal pada bank. Sallama (2005) mengungkapkan bahwa sukuk dapat memberikan pengaruh efisiensi biaya operasional dan pendapatan bagi hasil serta meningkatkan porsi pembiayaan mudharabah dan musyarakah. Menurut Ismal (2010) bank syariah dapat menerbitkan sukuk sebagai alternatif pembiayaan sebagai tindakan antisipatif terhadap penarikan deposito atau kegagalan proyek pembiayaan. Penerbitan sukuk dapat digunakan untuk tujuan yang berbeda sesuai kebutuhan perusahaan (Nagano, 2010).
Dari penerbitan sukuk yang dilakukan, emiten dapat meningkatkan nilai pemegang saham dan produktifitas perusahaan. Dalam menerbitkan sukuk, manajemen bank umum syariah akan memperhatikan sejumlah faktor yang diperlukan dalam pengambilan keputusan untuk menerbitkan sukuk. Sudarsono (2008) dalam menerbitkan sukuk ada beberapa fitur yang terkait yaitu: nilai emisi, jangka waktu sukuk, return pendapatan, jadwal pembayaran, dan jaminan. Dengan menggunakan metode gabungan antara studi literatur dan wawancara mendalam (indepth interview) serta menggunakan metode Analytical Network Process (ANP), penelitian ini berupaya mengidentifikasi sejumlah elemen penting dari para praktisi perbankan syariah yang telah menerbitkan sukuk atas sejumlah faktor dari fitur yang memengaruhi mereka dalam memutuskan menerbitkan sukuk. Dengan demikian bank syariah lain yang belum menerbitkan sukuk mendapatkan pengetahuan dan mengikuti untuk menerbitkan sukuk.

\section{Permasalahan}

Sampai dengan akhir September 2018, bank syariah mengalami sejumlah kendala yaitu memiliki keterbatasan modal dengan rasio kecukupan modal (CAR) BUS secara agregat hanya mencapai $21,25 \%$, lebih rendah dari CAR rata-rata bank umum secara nasional yang mencapai 22,91 \%. Selain itu, bank tinggi biaya pembiayaan kepada nasabah, bank akan kesulitan menjaga likuiditas dan membiayai pembiayaan yang bersifat jangka panjang. Salah satu alternatif cara yang dapat dilakukan oleh BUS adalah dengan mencari sumber pendanaan lain dengan menerbitkan sukuk. Akan tetapi ternyata masih sedikit BUS yang menerbitkan sukuk. Sampai dengan akhir September 2018, dari 14 BUS di Indonesia hanya 4 BUS yang telah menerbitkan sukuk, yaitu Bank Syariah Mandiri, Bank Muamalat Indonesia, Bank Negara Indonesia Syariah, dan Bank Rakyat Indonesia Syariah. Terdapat 10 BUS lagi yang belum pernah menerbitkan sukuk. Untuk memutuskan menerbitkan sukuk, manajemen BUS tentu akan memperhatikan sejumlah faktor dari fitur yang memengaruhi keputusan penerbitan sukuk. syariah juga mengalami kendala dalam meningkatkan efisiensi dimana tingkat BOPO bank syariah mencapai $88,08 \%$ bila dibandingkan dengan perbankan secara nasional yang mencapai $79,13 \%$. Kemudian 
komposisi Dana Pihak Ketiga (DPK) bank syariah selama ini didominasi dari sumber dana jangka pendek, yaitu dalam bentuk deposito. Inefisiensi ini menyebabkan semakin

\section{Tujuan}

Berdasarkan latar belakang penelitian dan permasalahan, maka penelitian ini bertujuan:

1. Untuk mengidentifikasi sejumlah elemen dan sub-elemen dalam fitur yang mempengaruhi Bank Umum Syariah dalam memutuskan menerbitkan sukuk

2. Untuk mengidentifikasi sejumlah elemen dan sub-elemen dalam fitur yang dominan mempengaruhi Bank Umum Syariah dalam memutuskan menerbitkan sukuk

3. Untuk memberikan rekomendasi yang relevan khususnya bagi Bank Umum Syariah dalam memutuskan menerbitkan sukuk.

\section{TINJAUAN PUSTAKA}

Wijnbergen dan Zaheer (2013), perbedaan utama antara sukuk dan obligasi konvensional adalah bahwa sukuk tidak melibatkan bunga transaksi berdasarkan karena larangan mereka disyariah. Seperti aset- konvensional backed securities (ABS), sukuk juga didukung oleh aset. Namun, perbedaan antara sukuk dan ABS konvensional adalah bahwa dikedua aset yang mendasari dapat menjadi aset keuangan seperti pinjaman atau piutang lain tetapi di sukuk hanya aset riil dapat digunakan sebagai jaminan. Penjualan utang tidak diperbolehkan dalam keuangan Islam, kecuali bila diperdagangkan pada pasar. Zin (2011), sukuk dapat terstruktur bersama teknik yang berbeda. Sementara obligasi konvensional adalah janji untuk membayar pinjaman, sukuk merupakan kepemilikan parsial dalam utang (Murabahah sukuk), aset (Al Ijarah sukuk), proyek (Al Istishna'a sukuk), bisnis (Al Musyarakah sukuk) atau investasi (Al Istithmar sukuk). Stuktur sukuk yang beragam tersebut, tidak ditemukan dalam Al- Qur'an dan Sunah namun merupakan hasil ijtihad berbasis konteks yang dikembangkan oleh para ulama dan pemikir Islam (Saeed dan Salah, 2013).

Al Saeed (2012), mengungkapkan bahwa secara perspektif, perusahaan menerbitkan sukuk sebagai diversifikasi sumber pendanaan. Kemudian secara harga sukuk dipengaruhi oleh keadaan krisis keuangan global, benchmark LIBOR, likuiditas dipasar sekunder dan harga pasar. Selain itu faktor yang mempengaruhi investor adalah struktur sukuk, aset yang dijaminkan dan transparansi yang detail terkait penerbitan sukuk. Said dan Grassa (2013), mendapatkan bahwa pertemuan banyak variabel mendorong pengembangan pasar sukuk. Faktor ekonomi makro seperti PDB per kapita, ukuran ekonomi, memiliki dampak positif dari pertumbuhan dari pasar sukuk. Selain itu, keterbukaan perdagangan juga memiliki efek positif. Kualitas regulasi memiliki dampak yang signifikan terhadap perkembangan pasar sukuk. Abdo (2014), mengungkapkan bahwa ada beberapa isu terkait dengan penerbitan sukuk, yaitu kebutuhan pasar sekunder, imbal hasil yang melihat pada benchmark market, standarisasi pada akad dan skema sukuk, ketersediaan aset yang dijaminkan dan kualitas regulasi terkait penerbitan sukuk.

Shahar et al (2014), mendapatkan bahwa dibandingkan dengan faktor-faktor tata kelola perusahaan, karakteristik perusahaan yaitu harga saham memiliki peran yang lebih menonjol dalam menjelaskan pilihan antara utang Islam dan utang konvensional.

\section{METODE PENELITIAN}

Penelitian ini merupakan gabungan penelitian kualitatif dan kuantitatif antara studi literatur dan wawancara mendalam (indepth interview) serta ANP. Studi literatur merupakan langkah awal untuk memperoleh informasi penelitian sejenis dan membuat kerangka dan desain pertanyaan (Zed, 2004), sedangkan metode wawancara mendalam adalah proses komunikasi atau interaksi dengan informan kunci yang dinilai memiliki pengetahuan yang luas dan memberikan informasi yang berharga untuk penelitian (Musianto, 2002). Metode ANP digunakan dalam bentuk penyelesaian dengan pertimbangan atas penyesuaian kompleksitas masalah secara penguraian sintesis disertai adanya skala prioritas yang menghasilkan pengaruh prioritas terbesar. ANP mampu menjelaskan model faktor-faktor dependence serta feedback-nya secara sistematik. Pengambilan keputusan dalam aplikasi ANP dengan melakukan pertimbangan dan validasi atas pengalaman empiris (Saaty, 2006). Sebelum melakukan wawancara, peneliti terlebih dahulu mencari studi literatur yang relevan terkait masalah peneltian dari buku, laporan publikasi 
regulator, jurnal, tesis dan disertasi untuk mendapatkan pengetahuan yang utuh terhadap permasalahan penelitian. Setelah itu, peneliti membuat pertanyaan yang terstruktur kepada para responden. Kemudian, jawaban dari para responden direkam dan dibuat dekomposisi. Setelah itu para responden menjawab kuisioner ANP berupa pairwise comparison (pembandingan pasangan) antar elemen dalam cluster untuk mengetahui mana diantara keduanya yang lebih besar pengaruhnya (lebih dominan) dan seberapa besar perbedaannya melalui skala numerik 1-9. Data hasil penilaian kemudian dikumpulkan dan diinput melalui software super decision untuk diproses sehingga menghasilkan output berbentuk prioritas dan supermatriks. Pemilihan responden dalam penelitian ini dilakukan secara purposive sampling dan convenience sampling. Pengambilan sampel tersebut termasuk dalam teknik sampel non probabilitas (Sekaran, 2003). Responden yang dipilih adalah para praktisi perbankan syariah yang memiliki pengetahuan dan pengalaman sehingga mendapatkan wawasan teoritis (Saunders dan Thornhill, 2012). Jumlah total responden dalam penelitian berjumlah 4 orang yang terdiri dari; Treasury Group Head PT Bank Syariah Mandiri (BSM), Treasury Division Head PT Bank Muamalat Indonesia (BMI), Treasury Manager PT Bank Negara Indonesia Syariah (BNIS), Treasury and International Banking Group Head PT Bank Rakyat Indonesia Syariah (BRIS).

\section{HASIL DAN PEMBAHASAN}

BUS dalam menerbitkan sukuk tentu akan mempertimbangkan unsur atau fitur yang melekat pada sukuk. Secara fitur sukuk terdiri dari a). Nilai emisi, b). Jangka waktu, c). Return, d). Jaminan dan e). Term pembayaran return. Setelah mengkaji literatur dan melakukan wawancara mendalam dari para responden, berikut gambaran aspek faktor dari fitur yang mempengaruhi Bank Umum Syariah (BUS) dalam memutuskan menerbitkan sukuk. Pada aspek fitur terdapat sub-elemen dengan rincian:

\section{a). Fitur Nilai Emisi}

Dalam fitur nilai emisi, terdapat 3 sub-elemen yang menjadi pertimbangan, atau mempengaruhi, yaitu i). Kebutuhan tambahan dana, ii). Kemampuan bayar perusahaan, dan iii). Kondisi makroekonomi.

Kebutuhan tambahan dana menunjukkan besaran kebutuhan tambahan dana bagi perusahaan. Dana yang terkumpul dapat dimanfaatkan untuk kebutuhan modal atau ekspansi pembiayaan. Dalam hal ini apabila perusahaan memutuskan menerbitkan sukuk, maka besaran nilai emisi dalam penerbitan sukuk, dipengaruhi seberapa besar kebutuhan tambahan dana yang diperlukan. Adapun kemampuan bayar perusahaan menunjukkan kemampuan perusahaan dalam membayar kembali dana investor pada saat jatuh tempo pengembalian sukuk (maturity). Kemampuan bayar ini agar menghindari terjadinya default risk. Dalam hal ini apabila perusahaan memutuskan menerbitkan sukuk, maka besaran nilai emisi dalam penerbitan sukuk, dipengaruhi kemampuan perusahaan dalam melunasi dana investor pada saat sukuk telah jatuh tempo (maturity). Kemudian kondisi makroekonomi menunjukkan kondisi makroekonomi yang sedang atau akan terjadi. Kondisi makroekonomi memiliki pengaruh terhadap daya serap pasar terkait nilai emisi yang diterbitkan. Dalam hal ini apabila perusahaan memutuskan menerbitkan sukuk, maka besaran nilai emisi dalam penerbitan sukuk, dipengaruhi keadaan makroekonomi yang sedang atau akan terjadi. Apabila kondisi makroekeonomi baik, maka perusahaan semakin percaya diri dalam menentukan besaran nilai emisi.

\section{b). Fitur Jangka Waktu}

Dalam fitur jangka waktu, terdapat 3 (tiga) sub-elemen yang menjadi pertimbangan, atau mempengaruhi, yaitu i). Reputasi/ size perusahaan, ii). Besaran nisbah bagi hasil/fee/jasa, dan iii). pengelolaan mismatch. Reputasi/size perusahaan menunjukkan reputasi/ image perusahaan atau size perusahaan yang dilihat dari total aset yang dimiliki. Dalam hal ini apabila perusahaan memutuskan menerbitkan sukuk, maka lamanya jangka waktu dalam penerbitan sukuk, dipengaruhi oleh reputasi/ size yang melekat pada perusahaan. Apabila reputasi/ size perusahaan dinilai baik oleh investor, maka perusahaan semakin percaya diri dalam menentukan lamanya jangka waktu penerbitan sukuk. Adapun besaran nisbah bagi hasil/fee/jasa menunjukkan besaran nisbah bagi hasil/fee/jasa yang disepakati bersama dengan investor dalam prospektus sukuk. Dalam hal ini apabila perusahaan memutuskan menerbitkan sukuk, maka lamanya jangka waktu dalam penerbitan sukuk, dipengaruhi besaran nisbah bagi hasil/fee/jasa yang telah 
disepakati. Kemudian pengelolaan mismatch menunjukkan perihal pengelolaan mismatch yang terjadi antara rata-rata jangka waktu DPK dengan pembiayaan/ proyek yang ada. Pertimbangan dalam mengelola mismatch ini menentukan pilihan bagi BUS dalam menentukan lamanya jangka waktu penerbitan sukuk.

\section{c). Fitur Return}

Dalam fitur return, terdapat 3 (tiga) sub-elemen yang menjadi pertimbangan, atau mempengaruhi, yaitu i). Ekspetasi investor, ii). Benchmark market dan iii). Jenis/ kinerja aset (financing project).

Ekspetasi investor menunjukkan ekspetasi terkait harapan pengembalian yang diinginkan oleh investor. Dalam hal ini apabila perusahaan memutuskan menerbitkan sukuk, maka besaran return dalam penerbitan sukuk, dipengaruhi harapan pengembalian yang diinginkan oleh investor. Apabila perusahaan mampu memenuhi hal tersebut, maka BUS semakin percaya diri dalam menentukan besaran return. Adapun benchmark market menunjukkan pertimbangan dalam membandingkan return sukuk yang ada pada pasar sukuk lokal. Dalam hal ini apabila perusahaan memutuskan menerbitkan sukuk, maka besaran return dalam penerbitan sukuk, dipengaruhi oleh benchmark return yang ada pada pasar lokal sukuk. Apabila perusahaan mampu memenuhi hal tersebut, maka perusahaan semakin percaya diri dalam menentukan besaran return. Kemudian jenis/kinerja aset (financing project) menunjukkan pilihan jenis aset atau kinerja aset yang menjadi sumber pendapatan dalam penerbitan sukuk. Dalam hal ini apabila perusahaan memutuskan menerbitkan sukuk, maka besaran return dalam penerbitan sukuk, berdasarkan jenis/kinerja pembiayaan yang menjadi sumber pendapatan dalam penerbitan sukuk.

\section{d). Fitur Jaminan}

Dalam fitur jaminan, terdapat 3 subelemen yang menjadi pertimbangan, atau mempengaruhi, yaitu i). Akad dan struktur sukuk, ii). Sharia compliance, dan iii). Bisnis model.

Akad dan struktur sukuk menunjukkan pilihan akad dan struktur/skema atas sukuk yang diterbitkan. Dalam hal ini apabila perusahaan memutuskan menerbitkan sukuk maka jaminan sukuk ditentukan berdasarkan akad dan struktur sukuk. Adapun syariah compliance menunjukkan bahwa perusahaan memperhatikan kepatuhan atas prinsip syariah (syariah compliance) atas jaminan yang diberikan oleh perusahaan dalam penerbitan sukuk. Kemudian Bisnis model menunjukkan bahwa perusahaan mempertimbangkan portofolio/segmentasi bisnis dalam sumber Dana Pihak Ketiga dan proyek pembiayaan yang sudah atau akan dilakukan sehingga jaminan yang dijadikan sumber pendapatan atas penerbitan sukuk berdasarkan model bisnis yang dominan dimiliki oleh perusahaan.

\section{e). Fitur Term Pembayaran}

Dalam fitur term pembayaran, terdapat 3 (tiga) sub-elemen yang menjadi pertimbangan, atau mempengaruhi, yaitu i). Preferensi investor/market, ii). Likuiditas perusahaan dan iii). Tenor sukuk.

\section{Preferensi}

investor/market menunjukkan bahwa perusahaan dalam menentukam term pembayaran return (imbal hasil), memperhatikan preferensi investor atau kelaziman term yang ada di pasar atau berdasarkan ketentuan yang berlaku. Adapun likuiditas perusahaan menunjukkan bahwa perusahaan memperhatikan kemampuan likuiditas terkait arus kas (cashflow) perusahaan dalam menentukan term pembayaran return. Kemudian tenor sukuk menunjukkan bahwa perusahaan dalam menentukan term pembayaran return (imbal hasil), memperhatikan lamanya waktu penerbitan sukuk.

Gambar 1 memperlihatkan secara ringkas sub-elemen yang terdapat pada aspek fitur:

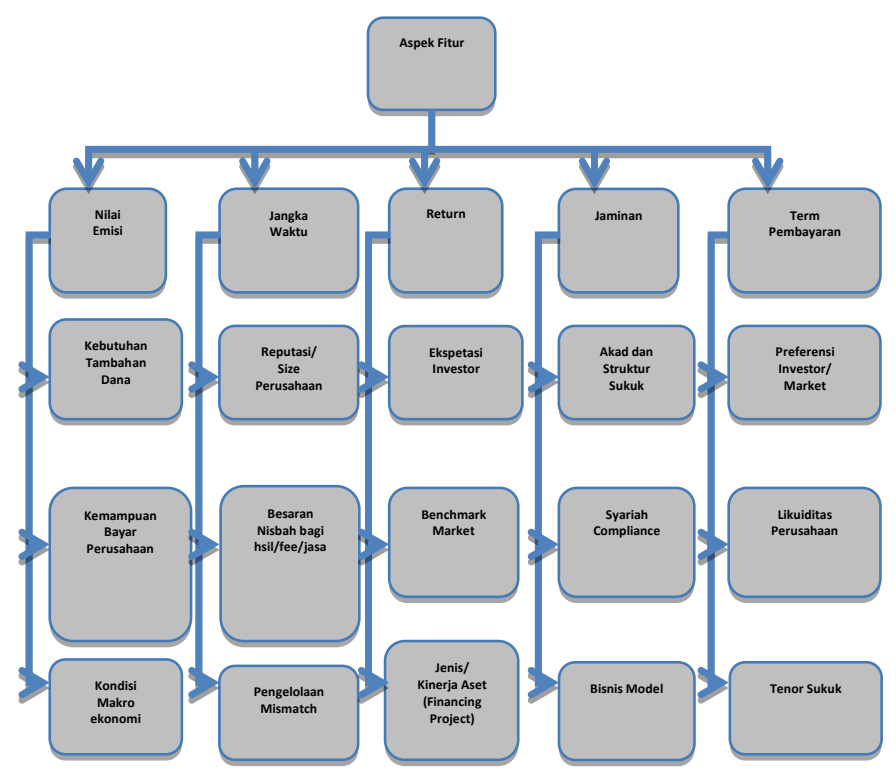


Gambar 1. Sub-Elemen Pada Aspek DENGAN MENGGUNAKAN METODE ANP, DIDAPATKAN HASIL PRIORITAS PADA ASPEK FITUR:

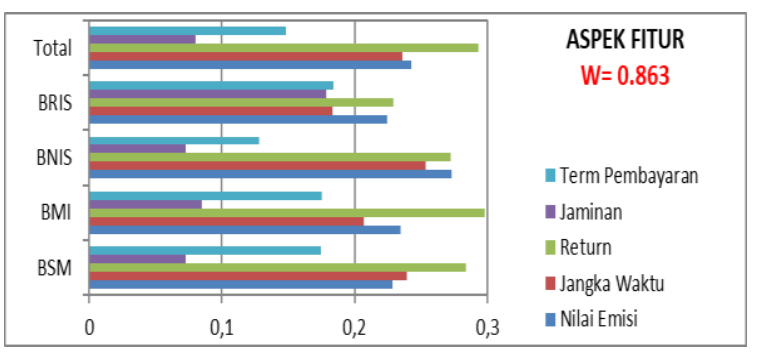

Gambar 2. Prioritas Aspek Fitur

Pada Gambar 2 dapat dilihat pada aspek fitur menurut praktisi BSM, BMI dan BRIS berpendapat sama bahwa elemen yang paling dominan menjadi pertimbangan dalam menentukan fitur atas penerbitan sukuk adalah return. Praktisi BNIS berpendapat berbeda, bahwa elemen yang paling dominan menjadi pertimbangan dalam menentukan fitur atas penerbitan sukuk adalah nilai emisi. Secara keseluruhan semua responden berpendapat bahwa fitur yang dominan bagi BUS dalam penerbitan sukuk adalah fitur return diikuti dengan fitur nilai emisi lalu fitur jangka waktu dengan nilai kesesuaian yang tinggi $(\mathrm{W}=$ 0.863). Dengan demikian dapat disimpulkan bahwa return, nilai emisi dan jangka waktu merupakan elemen yang dominan bagi BUS sebagai fitur atas penerbitan sukuk. Apabila BUS akan memutuskan menerbitkan sukuk, maka BUS dominan mempertimbangkan fitur return, nilai emisi dan jangka waktu.

Untuk lebih memberikan rincian terkait sub elemen yang penting bagi BUS dalam menentukan fitur atas penerbitan sukuk akan ditampilkan pada Gambar 3 berikut ini:

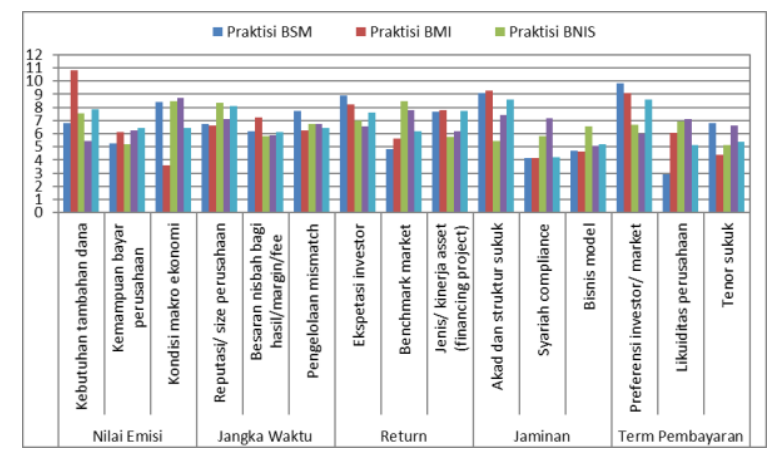

Gambar 3. Uraian Prioritas pada Aspek Fitur
Fitur

Dari Gambar 3 dapat disimpulkan menurut praktisi BSM bahwa preferensi investor/ market (fitur term pembayaran) merupakan sub-elemen yang terpenting sebagai fitur atas penerbitan sukuk, yaitu sebesar $9.86 \%$ sedangkan menurut praktisi BMI berpendapat bahwa sub-elemen yang terpenting adalah kebutuhan tambahan dana (fitur nilai emisi) sebesar $10.81 \%$ dan menurut praktisi BRIS adalah kondisi makro ekonomi (fitur nilai emisi) sebesar 8,71\%. Menurut praktisi BNIS dengan prosentase sebesar $8.47 \%$ bahwa benchmark market (fitur return) merupakan sub-elemen yang terpenting. Secara keseluruhan responden berpendapat bahwa preferensi investor/market (fitur term pembayaran) merupakan subelemen yang terpenting dalam sebagai fitur atas penerbitan sukuk dengan prosentase sebesar $8.61 \%$. Secara kombinasi faktor yang mempengaruhi BUS dalam menentukan fitur atas penerbitan sukuk secara berurutan yaitu: jenis/kinerja aset (return), kebutuhan tambahan dana (nilai emisi), dan reputasi/size perusahaan ((jangka waktu), preferensi investor/market (term pembayaran), serta akad dan struktur sukuk (jaminan).

\section{KESIMPULAN}

Berdasarkan hasil penelitian, didapatkan kesimpulan bahwa:

a) BUS dalam menerbitkan sukuk tentu akan mempertimbangkan unsur atau fitur yang melekat pada sukuk, terdiri dari i). Nilai emisi, ii). Jangka waktu, iii). Return, iv). Jaminan, dan v). Term pembayaran return. Sub-elemen yang penting bagi bank syariahdalam memutuskan menerbitkan sukuk pada Fitur Nilai Emisi: kebutuhan tambahan dana, kemampuan bayar perusahaan, dan kondisi makroekonomi. Pada Fitur Jangka Waktu: reputasi/size perusahaan, besaran nisbah bagi hasil/fee/jasa, dan pengelolaan mismatch. Pada Fitur Return: ekspektasi investor, benchmark market, dan jenis/kinerja aset (financing project). Pada Fitur Jaminan: akad dan struktur sukuk, syariah compliance, dan model bisnis. Pada Fitur Term Pembayaran: preferensi investor/market, likuiditas perusahaan, dan tenor sukuk. 
b) Dalam penerbitan sukuk, fitur yang dominan menjadi pertimbangan bagi Bank Umum Syariah adalah fitur return diikuti dengan fitur nilai emisi dan fitur jangka waktu. Adapun secara kombinasi subelemen dominan bagi BUS dalam menentukan fitur atas penerbitan sukuk secara berurutan adalah: jenis kinerja aset (return), kebutuhan tambahan dana (nilai emisi), dan reputasi/size perusahaan ((jangka waktu), preferensi investor/market (term pembayaran), serta akad dan struktur sukuk (jaminan).

c) Dalam memutuskan menerbitkan sukuk ada beberapa hal yang dapat dilakukan oleh BUS yaitu BUS terlebih dahulu menjaga kualitas aset atau financing project BUS tersebut. Kemudian BUS sedapat mungkin terlebih dahulu sudah mendapatkan MOU kerjasama proyek pembiayaan baik dengan sektor usaha BUMN maupun sektor swasta lainnya. Selain itu BUS harus juga memiliki manajemen pengelolaan risiko yang baik.

\section{SARAN}

Adapun saran yang dapat diberikan berdasarkan hasil pembahasan adalah:

a) Bank syariah yang belum menerbitkan sukuk.

Untuk menerbitkan sukuk, BUS perlu memperhatikan kemampuan BUS tersebut dalam memberikan return yang kompetitif bagi investor. Untuk itu BUS terlebih dahulu harus memperhatikan jenis dan dan kualitas kinerja aset (financing project) yang dimiliki BUS tersebut. Apabila elemen tersebut dinilai kuat maka BUS dapat mempertimbangkan untuk menerbitkan sukuk. Dalam hal ini BUS sedapat mungkin terlebih dahulu menjaga kualitas aset atau financing project BUS tersebut. Kemudian dalam fitur nilai emisi, bank umum syariah perlu memperhatikan kebutuhan tambahan dana. Dalam hal ini BUS sedapat mungkin terlebih dahulu sudah mendapatkan MOU kerjasama proyek pembiayaan baik dengan sektor usaha BUMN maupun sektor swasta lainnya. Setelah itu dalam fitur jangka waktu penerbitan sukuk, BUS terlebih dahulu menilai reputasi/size perusahaan yang dimiliki. Apabila elemen tersebut dinilai baik, maka BUS dapat lebih confident dalam memutuskan jangka waktu dalam penerbitan sukuk. Dalam hal ini BUS harus memiliki manajemen pengelolaan risiko yang baik.

b) Peneliti berikutnya

Penelitian berikutnya dapat dilakukan terhadap lembaga keuangan syariah atau jenis korporasi yang lain. Selain itu, penelitian juga dapat mengidentifikasi elemen penting dari sudut pandang investor terhadap penerbitan sukuk.

\section{DAFTAR PUSTAKA}

Abdo, Alaa. (2014). A Critical Review of the Sukuk Market A Qualitative Study to identify Curent Risks and Opportunities. Disertasi Dublin Business School.

Al Saeed, Khalid Sulaiman. (2012). Sukuk Issuance in Saudi Arabia: Recent Trends and Positive Expectations. Inggris: Tesis Durham University.

Diaw, Abdou., Obiyathulla Ismath Bacha and Ahcene Lahsasna. (2013). Incentive-Compatible Sukuk Musharakah for Private Sector Funding. International Centre for Education in Islamic Finance. MPRA Paper No. 46009, posted 20 April 2013.

Oh, Inha., Jeong Dong Lee, Seogwon Hwang and Almas Heshmati. (2009). Analysis of Product Efficiency in the Korean Automobile Market from a Consumer's Perspective. Springer

Ismal, Rifki. (2010). The Management of Liquidity Risk in Islamic Banks: The Case of Indonesia. Inggris: Disertasi Durham University.

Jobst, Andrea., Peter Kunzel., Paul Mills and Amadou Sy. (2008). Islamic Bond Issuance - What Sovereign Debt Managers Need to Know. International Journal of Islamic and Middle Eastern Finance and Management, Vol. 1, No. 4, pp. 330-344, 2008.

Musianto, Lukas S. (2002). Perbedaan Pendekatan Kuantitatif dengan Pendekatan Kualitatif dalam 
Metode Penelitian. Jurnal Manajemen dan Kewirausahaan Vol.4, No.2. Sepetember 2002.

Nagano, Mamoru. (2010). Islamic Finance and the Theory of Capital Structure . MPRA Paper No. 24567, posted 22. August 2010. Nagoya City University, Japan

Otoritas Jasa Keuangan. (2015). Peraturan Otoritas Jasa Keuangan No. 18/POJK.04/2015

Prabowo, T. (2003). Analisa Pengaruh Perubahan Struktur Modal dan Imunisasi Suku Bunga akibat Penerbitan Obligasi Subordinasi. Jakarta: Tesis Universitas Indonesia.

Saaty, Thomas L and Luis G. Vargas (2006). Decision Making with the Analitic Network Process. Economic, Political, Social and Technological Applications with Benefits, Opportunities, Costs and Risks. Springer. RWS Publication, Pittsburgh.

Saeed, A and Salah, O. (2013). Development of Sukuk: Pragmatic and Idealist Approaches to Sukuk Structures. Journal of International Banking Law and Regulation.

Said, Ali and Rihab Grassa. (2013). The Determinants of Sukuk Market Development: Does Macroeconomic Factors Influence the Construction of Certain Stucture of Sukuk?. Journal of Applied Finance \& Banking, vol. 3, no. 5, 2013, 251-267 ISSN: 17926580 (print version), 1792-6599 (online) Scienpress Ltd, 2013.

Sallama, N.I. (2005). Pengaruh Penerbitan Obligasi Subordinasi Terhadap Pembiayaan dan Kinerja Bank Syariah (Studi Kasus Bank Muamalat Indonesia). Jakarta: Tesis Universitas Indonesia.

Sapulete, Archie Marlon dan Adler Haymans Manurung. (2012). Pengaruh Penerbitan Obligasi Subordinasi dan Rasio Keuangan Terhadap Profitabilitas Bank.
Jakarta: Jurnal Akuntansi Universitas Tarumanegara

Saunders, Mark N.K., Philip Lewis and Adrian Thornhill. (2012). Research Methods For Business Students. 6thEdition. England: Pearson Education Limited.

Sekaran, Uma. (2003). Research Method for Business: A skill Building Approach. Fourth Edition. New Jersey. John Wiley \& Sons, Inc.

Setiawan, D.L. (2003). Analisa Pengaruh Perubahan Struktur Modal Sebelum dan Sesudah Penerbitan Obligasi Tehadap Kinerja Perbankan. Jakarta: Tesis Universitas Indonesia.

Shahar, Hanitta Bt Kadir., Yusnidah Ibrahim and Kamarun Nisham Taufil Mohd. (2014). Firms' Issuing Choice between Islamic and Conventional debt: Does Corporate Governance Stucture Matter?. Prosiding Persidangan Kebangsaan Ekonomi Malaysia ke9 (2014) 366 - 373 ISSN: 2231$962 X$.

Sudarsono, Heri. (2008). Bank dan Lembaga Keuangan Syariah. Yogyakarta: EKONISIA.

Usmani, Muhammad Taqi. (2008). Sukuk and their Contemporary Applications.

Wijnbergen, Sweder van and Sajjad Zaheer. (2013). Sukuk Defaults: On Distress Resolution in Islamic Finance, Tinbergen Institute Discussion Paper, No. 13-087/VI/ DSF57.

Zarqa, Muhammad Anas. (1997), Istisna Financing of Infrastructure Projects, in Ausaf Ahmad and Tariqullah Khan (eds), Islamic Financial Instruments for Public Sector Resource Mobilization, Jeddah: Islamic Research and Training Institute.

Zed, Mestika. (2004), Metode Penelitian Kepustakaan. Jakarta: Yayasan Obor Indonesia. 
Zin, Mohamad Zaid Mohd et al. (2011). The Effectiveness of Sukuk in Islamic Finance Market. Australian
Journal of Basic and Applied Sciences, 5(12): 472-478, 2011 ISSN

1991-81

\section{Lampiran. Definisi dan Referensi Sub-elemen Pada Aspek Fitur}

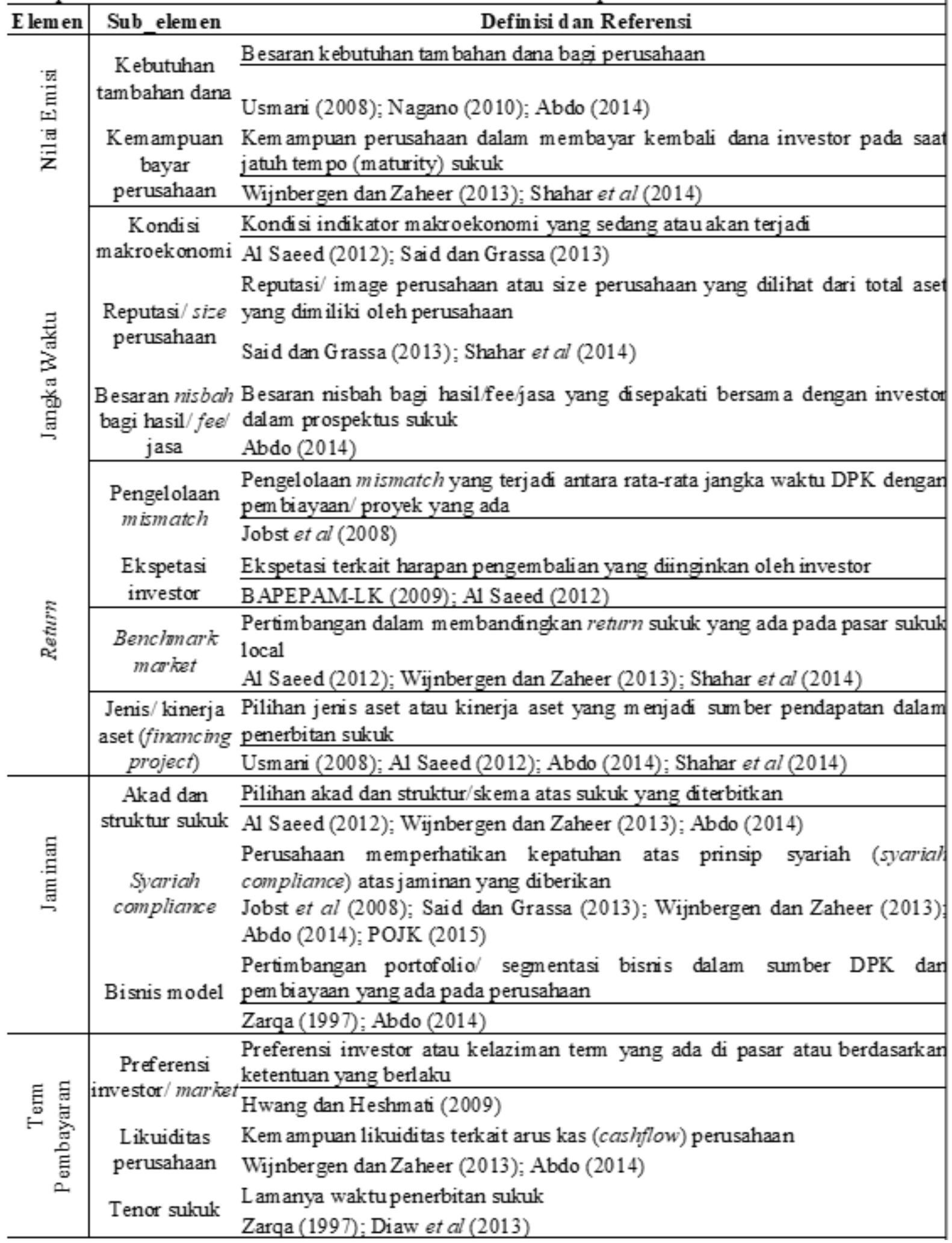

